\title{
Product configuration system and its impact on product's life cycle complexity
}

\author{
Myrodia, Anna; Kristjansdottir, Katrin; Shafiee, Sara; Hvam, Lars
}

Published in:

2016 IEEE International Conference on Industrial Engineering and Engineering Management (IEEM)

Publication date:

2016

Document Version

Peer reviewed version

Link back to DTU Orbit

Citation (APA):

Myrodia, A., Kristjansdottir, K., Shafiee, S., \& Hvam, L. (2016). Product configuration system and its impact on product's life cycle complexity. In 2016 IEEE International Conference on Industrial Engineering and Engineering Management (IEEM) IEEE.

\section{General rights}

Copyright and moral rights for the publications made accessible in the public portal are retained by the authors and/or other copyright owners and it is a condition of accessing publications that users recognise and abide by the legal requirements associated with these rights.

- Users may download and print one copy of any publication from the public portal for the purpose of private study or research.

- You may not further distribute the material or use it for any profit-making activity or commercial gain

- You may freely distribute the URL identifying the publication in the public portal

If you believe that this document breaches copyright please contact us providing details, and we will remove access to the work immediately and investigate your claim. 


\title{
Product configuration system and its impact on product's life cycle complexity
}

\author{
A. Myrodia, K. Kristjansdottir, S. Shafiee, L. Hvam \\ Department of Engineering Management, Technical University of Denmark, Kgs. Lyngby, Denmark \\ (annamyr@dtu.dk)
}

\begin{abstract}
The purpose of this paper is to identify areas throughout a product's lifecycle processes where complexity can be reduced by implementing a product configuration system (PCS). As discussed in the literature, several benefits are realized by using a PCS in terms of product and process standardization. This also leads to control and reduce of complexity both in products and processes. To this end, this research attempts to quantify and assess these benefits and is supported by empirical evidence. A case study of an engineering company is used and the results indicate significant improvements for the company in several life cycle processes.
\end{abstract}

Keywords - Complexity, Engineer-to-order companies Product configuration system (PCS), Product life cycle

\section{INTRODUCTION}

This paper aims to explore the overall impact on complexity reduction throughout the products' life cycle by implementing a product configuration system (PCS) in the early sales phase (Fig. 1). The literature describes various benefits that can be gained from implementing PCSs, however the connection between those benefits and the effects on complexity reduction in the different phases of the products' life cycles has not been explored to full extent. This research focuses on engineer-to-order (ETO) companies; companies considered are producing and selling complex and highly engineered products, such as cement or chemical factories, oilrigs etc.

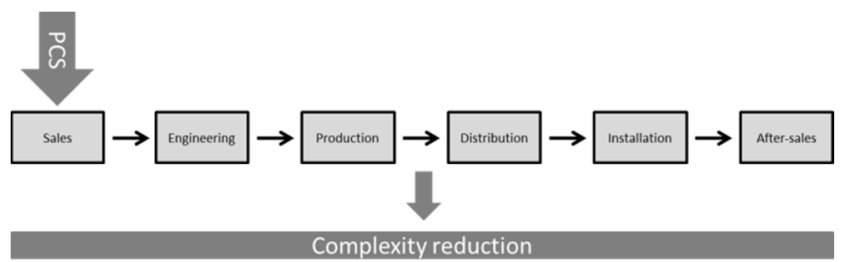

Fig. 1 - Impact of implementing PCSs in the sales process on the different phases of the product's life cycle.

PCS are widely used on products and services. With reference to products, they are utilized at different phases of a product's life cycle (design and engineering, sales, manufacturing, installation and after-sales) and various benefits have been discussed in the literature regarding lead times, quality, optimization of products and services etc. $[1,2]$. The complexity of handling information for a product increases the more complex and highly engineered the product is [3].

Regarding complexity in a manufacturing company, it can be identified in products, processes and organization [4], and it lies upon each of those aspects but also in their interrelationships $[5,6]$. There are several factors discussed in the literature related to complexity of products' life cycle [7].

Benefits of utilizing a PCS can be realized in the different life cycle processes and have an impact on several cost areas within a manufacturing company. As a result this research combines the fields of PCS and complexity, by assessing how product's life cycle complexity can be reduced by the utilization of a PCS. A case study is used to supplement this research.

\section{LITERATURE REVIEW}

\section{A. Benefits from using PCSs}

In this section the benefits from the utilization of a PCS identified in the literature are discussed and grouped according to different lifecycle processes.

PCSs have been implemented widely to support the specification process for the customized products and guide the sales process [8]-[10]. The benefits from applying PCSs can be described in terms of shorter-lead time and improved quality of the product's specifications, reduced resource consumption and increased customer satisfaction [11]. For that reason, less rework and less iterations are required, as the quality and the accuracy of quotations are increased [12]. Furthermore, PCSs can be used as tools that support sales persons to offer customized products within the boundaries of standard product architectures and thereby enable companies to be more in control of their product assortment $[2,13]$.

In order to achieve the benefits from a mass customization approach, utilization of PCSs and standardization of the product's architecture are considered as the main enablers $[14,15]$. The growing product variety at the companies has led to an increasing complexity of products and processes and to the need of better coordination of the way product specifications are performed [16]. PCS are used to support the product configuration processes, which consist of a set of activates that involves gathering information from customers and generation of all required product specifications $[2,16]$. In PCSs a set of components along with their connections 
are pre-defined and where constrains are used to prevent infeasible configurations [17].

Companies utilizing PCSs have achieved increased ability to manage product variety, improved product quality, simplification of the customer order process and complexity reduction [2], [18]-[20]. Furthermore, preservation of knowledge, use of fewer resources, optimization of products designs, less routine work, improved certainty of delivery, reduced time for training new employees and increased customer satisfaction [11], [16], [21]-[24] have been reported in the literature as benefits achieved via the use of a PCS. In addition, when the complete configuration process is supported by a PCS, the configuration cost may reduce up to $60 \%$ over the product lifecycle [13]. On the other hand, by utilizing a PCS companies can increase sales of more standardized products and become more in control of their product range, which can lead to higher efficiency, improved quality, and reduce the product complexity [2].

The following table demonstrates these benefits according to the different life cycle processes.

TABLE I

SUMMARY OF PCS's BENEFITS ON LIFE CYCLE PROCESSES

\begin{tabular}{|c|c|}
\hline Life cycle process & Benefit \\
\hline Sales & $\begin{array}{l}\text { Reduction in quotation lead time } \\
{[25]} \\
\text { Increase customer satisfaction } \\
\text { [26] } \\
\text { Improved communication and } \\
\text { relationship with customers [2], } \\
\text { [9], [10], [27]-[29] } \\
\text { Improved control of product } \\
\text { portfolio [2], [27], [29], [30] }\end{array}$ \\
\hline Engineering & $\begin{array}{l}\text { Reduction in lead time for } \\
\text { preparing specifications [31] } \\
\text { Increased quality of } \\
\text { specifications (less errors) [32] }\end{array}$ \\
\hline Production & $\begin{array}{l}\text { Reduction in work hours [12] } \\
\text { [33] } \\
\text { Reduction in hours making } \\
\text { production instructions [31] } \\
\text { Improved quality and number of } \\
\text { specifications that can be used } \\
\text { directly without iterations [16], } \\
\text { [33] }\end{array}$ \\
\hline Distribution & $\begin{array}{l}\text { Reduction in delivery time [31] } \\
\text { Improved on-time delivery [2], } \\
{[27],[30]}\end{array}$ \\
\hline Installation & $\begin{array}{l}\text { Reduction in number of errors } \\
\text { [31] }\end{array}$ \\
\hline After-sales & Improved efficiency [31] \\
\hline
\end{tabular}

\section{B. Complexity in product lifecycle processes}

Complexity is realized both in products and processes of the entire life cycle. Five areas of complexity are identified by [34]: product design, procurement, manufacturing process, product range, and distribution. Reference [35] distinguishes complexity cost between those that occur only once, at the introduction of the new variant, and those that re-occur during the entire lifecycle of the product. Reference [36] identifies and calculates the complexity costs for the business processes, by using a case study in the automobile manufacturing. The research concludes with the cost structure and the break-down of complexity costs to different processes. $15-20 \%$ of the total costs are considered as complexity costs, which are allocated to several business processes, such as inventory, production, logistics and sales.

The methods suggested reducing product complexity focus on increasing the overview and transparency of the product assortment [37] and improve product standardization [38]. Regarding methods for reduction of process complexity, optimization of the different lifecycle processes is discussed, in areas such as supplier-customer relationship [39], manufacturing process [40], production process [41], [42] and distribution [43]. Reference [44] suggests mass customization as a strategy for eliminating complexity caused by increasing variation in product architecture, inventory and order taking process.

\section{Bridging the gap between complexity and PCS}

Based on the literature discussed above, it can be concluded that PCS and complexity reduction are highly related topics within a manufacturing company. By implementing a PCS improved standardization of products and processes is achieved. Yet, through increased standardization complexity is also reduced in both the products and the life cycle processes. Hence, the direct impact of implementing a PCS on complexity is considered to be a great interest.

Therefore, this research studies the impact from implementing a PCS in the early sales phase on the complexity reduction through the entire life cycle of a product. In the early sales phase the most important decisions are taken and the characteristics of the products are determined. Based on the above, the following proposition is developed and tested in a case study.

Proposition $1(P)$ : Cost reduction is achieved through reducing complexity of a product's lifecycle processes by the use of a PCS.

The main proposition is divided into two parts, in order to be tested in the case study. The first one, studies the effect of reusing parts of completed projects to new ones. Then, a generalization of this concept is examined through the implementation of a PCS.

Proposition la (Pla): If it possible to reuse parts of the design of new projects from completed ones, then a significant reduction of costs of engineering, production and repairs after installation due to defects is achieved.

Proposition $1 b$ (P1b): Application of PCS in the sales phase and increase of modular product range may lead to more standardized products and benefits proved in $\mathrm{Pla}$ indicate the scale of possible savings.

\section{CASE STUDY}




\section{A. Introduction and Problem analysis}

The company selected as a case study in order to test the suggested proposition is an ETO manufacturer in the oil and gas industry. The company provides single equipment and complete systems and services and it operates worldwide. This specific company is chosen as a case study to be further investigated as it is considered to be highly representative in the engineering industry, so replication of the research could be ensured.

Data collection includes the cost for all the complete systems (projects) and single equipment (products) sold over a four-year period. The unit of analysis is the number of sales including projects and products. The related costs refer to the different phases of the products lifecycle, such as sales, engineering, production, distribution, installation and after-sales. Data were obtained through the company's internal database and verified by specialists within the company (project managers).

In detail, the different cost categories that are taken into consideration for the analysis are the following: inventory, material, engineering, production, assembly, outsourced parts and services, installation. The inventory cost and production account for more than $50 \%$ of the total cost both for projects and single products. The cost of engineering for the projects varies from $10 \%$ to $20 \%$ of the total cost, while for single products is $6 \%$. These two cost groups account for the largest share of the total cost.

In the four-year time period, the company sold 12 projects and 193 single products. Based on the data acquired, the revenue for the projects is 743,5 m€ and for the single products $46,5 \mathrm{~m} €$. Respectively, the costs are 758,7 m€ for the projects and 30,9 m€ for the single products. It can be seen from the numbers above that even though the projects create higher revenue compared to the sales of single equipment, the related costs are even higher, resulting in loss for the company. Furthermore, for the projects sold a deviation is identified between the estimated cost and revenue at the beginning of the project, when the budget is calculated, and the actual ones, when the project is finished.

These deviations can be due to external factors, such as currency, fluctuation on material price and labor cost. However, there are internal factors that also influence the increase of the estimated cost and revenue, and they need to be further investigated.

To this end, an area of interest identified during the analysis of the financial performance of the projects is the reduction of cost through repetition. When a project is reproduced based on an existing one, several cost categories are identified to have noteworthy reductions.

Engineering costs, which are calculated based on the hours spent for each project or product, seem to benefit from re-using existing documentation. The following figure illustrates the amount of hours spent on engineering for the pioneer project and for the projects reusing parts.

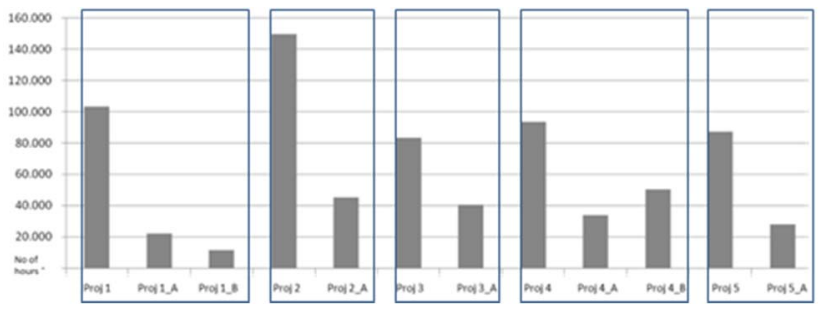

Fig. 2. No of engineering hours spent on original projects and projects reusing parts.

A trend can be seen, that for the projects that are replicated the engineering cost is always reduced. Only Proj 4_B, which is the second project created based on the initial Proj 4, is an outlier. This is explained by the fact that Proj 4_B is only partly a copy of the initial project.

The figure below illustrates a similar effect on the production costs through reusability of existing material, such as drawings, instructions and documentation.

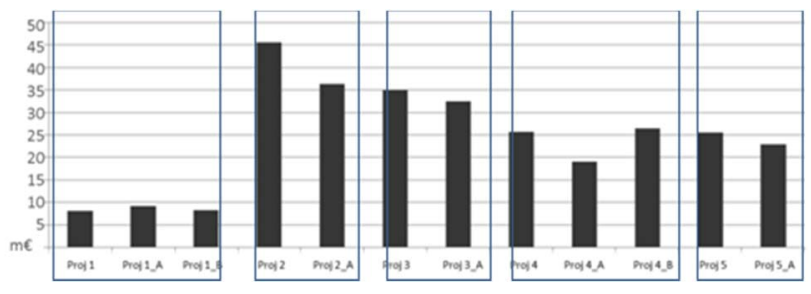

Fig. 3. Production costs of original projects and projects reusing parts.

Engineering and production costs account for more than $50 \%$ of the total cost, as explained before. As a result, these savings through re-usability and standardization of the processes could have a significant impact on the overall financial performance of the company.

Another cost area that showed significant savings in that aspect is the repairs after installation due to defects. The results can be seen in the following figure.

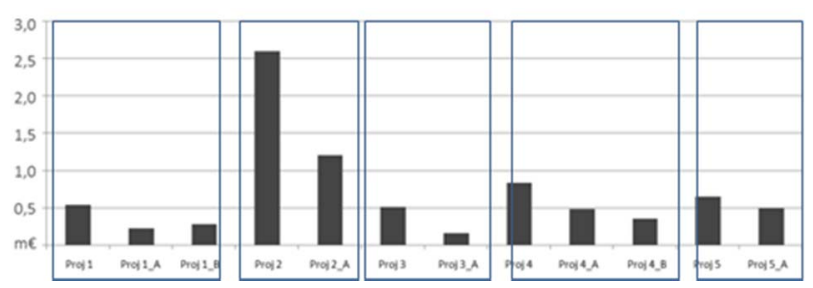

Fig. 4. Costs of repairs after installation due to defects for original projects and projects reusing parts.

This trend of cost reduction through reusability is also identified in other costs which are related to different life cycle processes, such as the revisions of drawings and changes on the drawings, outsourced production equipment and commissioning. The results from the figures above verify proposition 1a.

Nevertheless, deviations on the estimated costs and actual ones for the projects which are reusing parts is 
reported. Even though there is a significant reduction in various cost areas, still the company did not managed to reduce the cost to the desirable limit. And that is the reason why there is no profit gained for the sales of the projects.

\section{B. Results and Methods for Improvement}

Based on the analysis of the financial performance of the company two main areas of potential improvement can be identified as discussed in the literature [38], [45]; standardization and reusability. In order to achieve these improvements, firstly, the company should increase the standardization of the product portfolio. By changing or adjusting the products' architecture, the company can seize the benefits of complexity reduction in the product assortment. Then, the standardization of the processes and the increase in material reusability can be achieved by implementing a PCS. Through the utilization of a PCS both product and process complexity can be reduced and this would have a direct effect of cost savings.

In order to assess the potential benefits of suggested method, a sensitivity analysis is performed on the main cost areas, as they were identified in the section above. The table below indicates the main cost areas and the scenarios developed to estimate the potential benefits.

TABLE II

ASSESSMENT SCENARIOS

\begin{tabular}{rccc}
\hline Cost areas & Conservative & Realistic & Optimistic \\
\hline $\begin{array}{r}\text { Engineering } \\
\text { hours }\end{array}$ & $5 \%$ & $10 \%$ & $20 \%$ \\
$\begin{array}{r}\text { Production } \\
\text { costs }\end{array}$ & $10 \%$ & $20 \%$ & $30 \%$ \\
$\begin{array}{r}\text { Repairs after } \\
\text { installation }\end{array}$ & $30 \%$ & $50 \%$ & $80 \%$ \\
\hline
\end{tabular}

The scenarios are implemented to both the 12 projects and the 193 single products, which were also used for the analysis of above. The results of the sensitivity analysis are illustrated in the following table.

TABLE III

SCALE OF SAVINGS FOR THE SCENARIOS

\begin{tabular}{rccc}
\hline Cost areas & Conservative & Realistic & Optimistic \\
\hline $\begin{array}{r}\text { Engineering } \\
\text { hours [m€] }\end{array}$ & 1,9 & 3,8 & 7,6 \\
$\begin{array}{r}\text { Production } \\
\text { costs [m€] }\end{array}$ & 33,6 & 67,2 & 100,8 \\
$\begin{array}{r}\text { Repairs after } \\
\text { installation } \\
\text { [m€] }\end{array}$ & 2,8 & 4,5 & 7,1 \\
\hline Total [m€] & 38,3 & & \\
\hline
\end{tabular}

As it can be seen from Table III the potential savings in all the cost groups taking into consideration in the sensitivity analysis vary from $38,3 \mathrm{~m} €$ for the conservative approach to $115,5 \mathrm{~m} €$ for the optimistic scenario. These results showing significant potential for further cost reductions and the scale of possible savings, so they are aligned with the proposition $1 \mathrm{~b}$.

\section{DISCUSSION AND CONCLUSION}

The scope of this study is to identify how the costs vary between different projects in an engineering company with particular focus on the effect of having more standardized product designs in the projects. The study reveals that when projects are repeated using similar equipment from a previous project then the cost will be significantly reduced.

Literature claims that use of modularization and configuration systems would lead to more standardized projects and thus to cost reduction. This study reveals that if it is possible to base an engineering project on previously designed parts then it is possible to obtain some very significant savings. This indicates the scale of potential savings that may be obtained by applying modularization of the products in the projects and by using product configuration systems for actually selling these more standardized solutions.

Additional examples from engineering companies have to be added in the future in order to ensure generalizability of the suggested method.

\section{REFERENCES}

L. Hvam, "Observed benefits from product configuration systems," Int. J. Ind. Eng., vol. 20, no. 56, pp. $329-338,2013$.

[2] C. Forza and F. Salvador, "Managing for variety in the order acquisition and fulfilment process: The contribution of product configuration systems," Int. $J$. Prod. Econ., vol. 76, no. 1, pp. 87-98, Mar. 2002.

[3] H. P. L. Bruun, N. H. Mortensen, U. Harlou, M. Wörösch, and M. Proschowsky, "PLM system support for modular product development," Comput. Ind., vol. 67, pp. 97-111, Feb. 2015.

[4] S. A. Wilson and A. Perumal, Waging War on Complexity Costs. McGraw-Hill International Editions, 2009.

[5] T. Blecker, N. Abdelkafi, B. Kaluza, and G. Friedrich, "Controlling variety-induced complexity in mass customisation: a key metrics-based approach," Int. J. Mass Cust., Jan. 2006.

[6] S. N. Samy and H. A. ElMaraghy, "Complexity mapping of the product and assembly system," Assem. Autom., vol. 32, no. 2, pp. 135-151, 2012.

[7] W. Elmaraghy, H. Elmaraghy, T. Tomiyama, and L. Monostori, "Complexity in engineering design and manufacturing," CIRP Ann. - Manuf. Technol., vol. 61, no. 2, pp. 793-814, 2012.

[8] L. L. Zhang, "Product configuration: a review of the state-of-the-art and future research," Int. J. Prod. Res., vol. 52, no. 21, pp. 6381-6398, Aug. 2014.

[9] M. Gronalt, M. Posset, and T. Benna, "Standardized Configuration in the Domain of Hinterland Container Terminals," Ser. Bus. Informatics ..., 2007.

[10] P. J. P. Slater, "Pconfig: a Web-based configuration tool for Configure-To-Order products," KnowledgeBased Syst., vol. 12, no. 5-6, pp. 223-230, Oct. 1999. 
[11] L. Hvam, J. Riis, and N. H. Mortensen, Product customization. Berlin Heidelberg: Springer, 2008.

[12] L. Hvam, M. Malis, B. Hansen, and J. Riis,

"Reengineering of the quotation process: application of knowledge based systems," Bus. Process Manag. J., vol. 10, no. 2, pp. 200-213, Apr. 2004.

[13] G. Fleischanderl, G. E. Friedrich, A. Haselböck, H. Schreiner, and M. Stumptner, "Configuring large systems using generative constraint satisfaction," IEEE Intell. Syst., 1998.

[14] B. J. Pine II, B. Victor, and Boyton, "Making mass customization work," Harv. Bus. Rev., vol. 71, no. 5, pp. 109-119, 1993.

[15] F. Piller and P. Blazek, "Core capabilities of sustainable mass customization," ... Config. Res. to Bus. Cases. ..., 2014.

[16] C. Forza and F. Salvador, Product information management for mass customization. New York: Palgrave Macmillan, 2007.

[17] A. Felfernig, G. E. Friedrich, and D. Jannach, "UML as Domain Specific Language for the Construction of Knowledge-based Configuration Systems," Int. J. Softw. Eng. Knowl. Eng., vol. 10, no. 4, pp. 449-469, 2000.

[18] L. L. Zhang, E. Vareilles, and M. Aldanondo, "Generic bill of functions, materials, and operations for SAP2 configuration," Int. J. Prod. Res., vol. 51, no. 2, pp. 465-478, Jan. 2013.

[19] A. Trentin, E. Perin, and C. Forza, "Product configurator impact on product quality," Int. J. Prod. Econ., vol. 135, no. 2, pp. 850-859, Feb. 2012.

[20] F. Salvador and C. Forza, "Configuring products to address the customization-responsiveness squeeze: A survey of management issues and opportunities," Int. J. Prod. Econ., vol. 91, pp. 273-291, 2004.

[21] F. Piller, K. Moeslein, and C. Stotko, "Does mass customization pay? An economic approach to evaluate customer integration," Prod. Plan. Control, 2004.

[22] A. Felfernig, D. Jannach, and M. Zanker, "Contextual diagrams as structuring mechanisms for designing configuration knowledge bases in UML," «UML》 2000-The Unified Model. ..., 2000.

[23] L. Ardissono, A. Felfernig, G. Friedrich, A. Goy, D. Jannach, G. Petrone, R. Schäfer, and M. Zanker, "A framework for the development of personalized, distributed web-based configuration systems," AI Mag., vol. 24, no. 3, pp. 93 - 108, 2003.

[24] L. L. Zhang, "Product configuration: a review of the state-of-the-art and future research," Int. J. Prod. Res., vol. 52, no. 21, pp. 6381-6398, Aug. 2014.

[25] A. Haug, L. Hvam, and N. H. Mortensen, "The impact of product configurators on lead times in engineeringoriented companies," Artif. Intell. Eng. Des. Anal. Manuf., vol. 25, no. 02, pp. 197-206, Apr. 2011.

[26] V. E. Barker, D. E. O'Connor, J. Bachant, and E. Soloway, "Expert systems for configuration at Digital: $\mathrm{XCON}$ and beyond," Commun. ACM, vol. 32, no. 3, pp. 298-318, Mar. 1989.

[27] C. Forza and F. Salvador, "Product configuration and inter-firm co-ordination: an innovative solution from a small manufacturing enterprise," Comput. Ind., vol. 49, no. 1, pp. 37-46, Sep. 2002.

[28] J. Heatley, "AN EVALUATION OF AN INNOVATIVE INFORMATION TECHNOLOGY THE CASE OF CARRIER EXPERT,” J. Strateg. Inf.
Syst., vol. 4, no. 3, pp. 255 - 277, 1995.

[29] C. Forza and F. Salvador, "Application support to product variety management," Int. J. Prod. Res., vol. 46, no. 3, pp. 817-836, Feb. 2008.

[30] A. Tenhiälä and M. Ketokivi, "Order Management in the Customization-Responsiveness Squeeze*," Decis. Sci., 2012.

[31] L. Hvam, "Mass Customization in the electronics industry," Int. J. Mass Cust., vol. 1, no. 4, pp. 410 426, 2006.

[32] C. Forza and F. Salvador, "Managing for variety in the order acquisition and fulfilment process: The contribution of product configuration systems," Int. J. Prod. Econ., vol. 76, no. 1, pp. 87-98, Mar. 2002.

[33] M. Heiskala, K.-S. Paloheimo, and J. Tiihonen, Mass Customisation of Services: Benefits and Challenges of Configurable Services. Tampere, Finland, 2005.

[34] G. Foster and M. Gupta, "Manufacturing overhead cost driver analysis," J. Account. Econ., vol. 12, no. 1-3, pp. 309-337, 1990

[35] P. J. Rathnow, Integriertes Variantenmanagement: Bestimmung, Realisierung und Sicherung der optimalen Produktvielfalt. Gottingen: Vandehoeck \& Ruprecht, 1993.

[36] G. Rommel, F. Brück, R. Diederichs, R.-D. Kempis, and G. B. Rommel, Einfach überlegen: Das Unternehmenskonzept, das die Schlanken schlank und die Schnellen schnell macht. Stuttgart: SchäfferPoeschel, 1993.

[37] T. Suzue and A. Kohdate, Variety Reduction Program: A Production Strategy for Product Diversification. Cambridge, MA: Productivity Press, 1990.

[38] J. (Roger) Jiao, T. W. Simpson, and Z. Siddique, "Product family design and platform-based product development: a state-of-the-art review," J. Intell. Manuf., vol. 18, no. 1, pp. 5-29, Jul. 2007.

[39] S. Sivadasan, J. Efstathiou, G. Frizelle, R. Shirazi, and a. Calinescu, "An information-theoretic methodology for measuring the operational complexity of suppliercustomer systems," Int. J. Oper. Prod. Manag., vol. 22, no. 1, pp. 80-102, 2002.

[40] G. Frizelle and E. Woodcock, "Measuring complexity as an aid to developing operational strategy," Int. J. Oper. Prod. Manag., vol. 15, no. 5, pp. 26-39, May 1995.

[41] X. De Groote, "Flexibility and marketing/manufacturing coordination," Int. J. Prod. Econ., vol. 36, no. 2, pp. 153-167, Sep. 1994.

[42] K. Ramdas, "Managing product variety: An integrative review and research directions," Prod. Oper. Manag., vol. 12, no. 1, pp. 79-101, Jan. 2009.

[43] X. Wan, P. T. Evers, and M. E. Dresner, "Too much of a good thing: The impact of product variety on operations and sales performance," J. Oper. Manag., vol. 30, no. 4, pp. 316-324, May 2012.

[44] T. Blecker, N. Abdelkafi, B. Kaluza, and G. Kreutler, "A framework for understanding the interdependancies between mass customization and complexity," in Proceedings of the 2nd International Conference on Business Economics, Management and Marketing, 2004, pp. 1-15.

[45] T. Blecker and N. Abdelkafi, "Complexity and variety in mass customization systems: analysis and recommendations," Manag. Decis., vol. 44, no. 7, pp. 908-929, Aug. 2006. 